\title{
PERMAINAN CONGKAK: Nilai dan Potensinya bagi Perkembangan Kognitif Anak
}

\author{
Oleh Dheka D. A. Rusmana \\ Fakultas Ilmu Seni dan Sastra Universitas Pasundan \\ Jalan Dr. Setiabudhi No.193 Bandung 40154 \\ Email: dd_agusti@yahoo.co.id \\ Naskah diterima: 30 Juni 2010 \\ Naskah disetujui: 6 September 2010
}

\begin{abstract}
Abstrak
Penelitian berjudul Permainan Congkak: Nilai dan Potensinya bagi Perkembangan Kognitif Anak ini dilatarbelakangi oleh ketertarikan penulis terhadap permainan tradisional yang merupakan warisan nenek moyang. Interpretasi yang penulis lakukan berupaya menggali nilai dan potensi yang terdapat dalam permainan Congkak dalam hubungannya dengan bidang psikologi khususnya perkembangan anak. Penelitian terhadap permainan tradisional sebagai salah satu bentuk folklor Nusantara secara interdisipliner terhadap ilmu psikologi ini mengungkapkan bahwa permainan Congkak sebagai permainan tradisional yang berkembang di banyak daerah di Nusantara ini memiliki berbagai nilai dan memiliki potensi dalam memengaruhi perkembangan anak khususnya pada aspek kognitif.
\end{abstract}

Kata kunci: congkak, nilai, kognitif, anak.

Abstract

The research tittle is Congkak's Game: Potential and Values for Children Kognitive Development. The research background is interest of writer about traditional games, which is a legacy of our ancestor. The writer interpretation has found a potential corelations in Congkak's game in childrens kognitive development. The research about traditional games as one of the form in archipelago folklore interdisciplinary toward psychology science in children development, and revealed that Congkak's game has a potential and values in influencing children development especially in cognitif aspect.

Keywords: congkak, values, cognitif, childrens.

\section{A. PENDAhuluan}

Dalam era globalisasi ini, ketika teknologi dan informasi tumbuh dengan pesat, permainan tradisional semakin terpinggirkan. Permainan yang umumnya cenderung berkembang di masyarakat perkotaan lebih bersifat individual, dan ditinjau dari aspek finansial juga relatif mahal. Permainan tradisional anak pada dasarnya merupakan sebuah pembelajaran bagi anak-anak, dalam memainkannya anakanak dilatih untuk dapat mengoptimalkan akal, rasa, hati, jiwa, dan raganya.

Salah satu permainan tradisional adalah Congkak, atau dikenal juga dengan sebutan Congklak atau Dakon. Congkak adalah permainan rakyat yang sudah berkembang cukup lama di kawasan Melayu dengan sebutan yang 
berbeda-beda: di Malaysia dan beberapa daerah di kepulauan Riau dikenal dengan sebutan Congklak, di Filipina disebut Sungka, di Sri Lanka dikenal dengan Cangka, di Thailand Tungkayon, dan di beberapa daerah lain di Indonesia seperti di Sulawesi disebut Mokaotan, Maggaleceng, Aggalacang dan Nogarata. Ada juga yang menyebutnya Congkak seperti daerahdaerah yang ada di pulau Jawa.

Tersisihnya permainan tradisional permainan Congkak, sebenarnya merupakan kondisi yang alamiah dan tidak dapat ditolak. Tetapi jika dipertimbangkan kembali mengenai kandungan yang terdapat dalam permainan tradisional tersebut, sayang rasanya jika membiarkannya tidak berguna begitu saja menunggu waktu punahnya. Oleh karena itu, permainan Congkak akan dikaji secara interdisipliner untuk mengetahui kaitan manfaatnya ditinjau dari bidang psikologi.

Adapun rumusan masalah dalam penelitian ini yaitu: 1. Bagaimana konteks pertunjukan permainan Congkak? 2. Nilai dan potensi kognitif apakah yang terkandung dalam permainan Congkak?

Tujuan dari penelitian ini yaitu: 1. Mendeskripsikan konteks pertunjukan permainan Congkak. 2. Mendeskripsikan nilai dan potensi yang terkandung dalam permainan Congkak. Penulis menentukan ruang lingkup penelitian, sebagai berikut: 1) Permainan Congkak sebagai permainan tradisional anak atau yang sering disebut juga sebagai Congklak, Dakon, dan sebagainya, yang menggunakan papan Congkak berisi $2 X 7$ cekungan, dan 2 cekungan indung, serta 98 biji kuwuk. 2) Permainan Congkak ini digali dari masyarakat Sunda yang secara geografis menempati wilayah Jawa Barat, yaitu Bandung.

Permainan merupakan media pendidikan bagi seorang anak, sebab itulah tak ada orang tua yang melarang anaknya yang sering bermain. Selain menjadi media pembelajaran, permainan juga ditangani secara profesional oleh seorang ahli. Hal ini seperti tercermin pada pada masyarakat Sunda. Hempul, demikian istilah bagi orang yang ahli dalam permainan beserta sifat dan maknanya.

Berdasarkan perbedaan sifat permainan, Roberts, Arts, dan Bush, dalam Danandjaja, mengungkapkan bahwa permainan rakyat (folk games) dapat dibagi menjadi dua golongan besar yaitu permainan untuk bermain (play) dan permainan untuk bertanding (game). Bermain merupakan dunia anak. Anak tumbuh dan berkembang dalam kesehariannya bersama permainan. Meskipun bermain identik dengan dunia anak, tetapi pada dasarnya setiap orang senang bermain, baik ketika kita kecil, remaja, dewasa, bahkan orang tua.

Bermain ketika kita masih kecil seakan menjadi miniatur kehidupan kita kala dewasa. Merunut pada sudut pandang psikologi, mulai akhir tahun 1800-an bermain dipandang sebagai aktivitas yang penting untuk anak. Namun, sebelumnya aktivitas bermain hanyalah dipandang sebagai ekspresi dari kelebihan energi yang dimiliki anak-anak atau bermain merupakan bagian dari sebuah ritual budaya dan agama. Seiring perkembangan zaman, pandangan para ahli tentang bermain 
mulai berubah, dan bermain dipandang sebagai perilaku yang bermakna.

Perilaku bermain ini kemudian menjadi bagian yang penting dari teoriteori psikologi perkembangan. Freud berpendapat bahwa perilaku anak yang terlihat merupakan sebuah refleksi dari masalah-masalah dan konflik-konflik yang tidak disadari. Erikson juga mulai mempublikasikan karyanya tentang anak dan remaja. Mendasarkan pada teori perkembangan psikososialnya, Erikson memandang bermain sebagai sebuah ekspresi kombinasi beberapa kekuatan, yaitu: perkembangan individual, dinamika keluarga, dan harapan masyarakat.

Piaget dengan teorinya tentang perkembangan kognitif juga memberi perhatian pada perilaku bermain. Menurutnya, perubahan perilaku bermain menunjukkan perkembangan intelektual, sama seperti peningkatan kompetensi individu. Bermain juga menjadi media bagi individu untuk mempraktikkan apa yang sudah dipelajarinya. Menurut Axline, dalam situasi bermain anak-anak menampilkan diri mereka dengan cara yang paling terus terang, jujur, dan jelas. Perasaan, sikap, dan pikiran-pikiran mereka yang muncul, terbuka dengan jelas dan tanpa usaha untuk ditutuptutupi. Anak-anak juga belajar memahami diri mereka dan orang lain dengan lebih baik lewat bermain. Mereka belajar bahwa ketika bermain mereka dapat melakukan apa pun.

Menurut McCune, Nicolich, \& Fenson (dalam Schaefer, et al., 1991) bermain dibedakan dari perilaku yang lain dalam hal: (a) ditujukan demi kesenangan sendiri; (b) fokus lebih pada makna daripada hasil akhir; (c) diarahkan pada eksplorasi subjek untuk melakukan sesuatu pada objek; (d) tanpa mengharapkan hasil serius; (e) tidak diatur oleh aturan eksternal; (f) adanya keterikatan aktif dari pemainnya. Sedangkan Garvey dan Piaget menambahkan bahwa permainan haruslah: (a) menyenangkan; (b) spontan, sukarela, motivasinya instrinsik; (c) fleksibel; dan (d) berkait dengan pertumbuhan fisik dan kognitif.

Berdasarkan beberapa definisi tersebut maka dapat disimpulkan bahwa permainan adalah aktivitas yang mengandung motivasi instrinsik, dapat memberi kesenangan dan kepuasan bagi siapa yang terlibat.

Metode yang digunakan dalam penelitian ini adalah metode deskripsi analisis, yang bersifat kualitatif. Yaitu suatu metode yang digunakan untuk memecahkan masalah yang ada, dan menafsirkan data yang tersedia untuk kemudian dianalisis dengan diinterpretasikan. Deskriptif adalah penggambaran suatu peristiwa yang sedang terjadi. Penggambaran meliputi keseluruhan pertunjukan, sedangkan analisis adalah proses mengaitkan antara variabel satu dengan yang lainnya.

\section{B. HASIL DAN BAHASAN}

Deskripsi Permainan Congkak, meliputi: nama, alat yang digunakan, waktu permainan, tempat permainan, pihak yang terlibat, proses penciptaan, dan konteks pertunjukan.

\section{Alat yang Digunakan}

\section{a. Papan Congkak}

Papan Congkak, biasanya terbuat dari kayu (tetapi sekarang sudah banyak yang terbuat dari plastik) berbentuk seperti perahu dengan 
ukuran kurang lebih: panjang $80 \mathrm{~cm}$, lebar $15 \mathrm{~cm}$, dan tinggi $10 \mathrm{~cm}$. pada kedua ujungnya terdapat cekungan yang besar dan disebut indung. Antara kedua indung tersebut berderet dua yang masing-masing terdiri atas 7 cekungan yang lebih kecil, kira-kira berdiameter $5 \mathrm{~cm}$.

\section{b. Kuwuk}

Alat tersebut dilengkapi kuwuk atau kerikil atau biji-bijian apa saja yang berukuran kecil. Setiap cekungan (kecuali indung) harus diisi 7 buah butir. Sehingga seluruhnya memerlukan 98 butir (dua deret X \& lubang X 7 butir).

\section{Waktu Permainan}

Waktu permainan dapat dilakukan kapan saja, pada waktu senggang. Tempat permainan: di dalam atau di luar rumah, baik di teras maupun di halaman. Permainan ini tidak menyita banyak tempat.

\section{Pihak yang Terlibat dalam Permainan:}

Permainan ini biasanya dilakukan oleh perempuan, baik anakanak maupun dewasa. Pemain berjumlah dua orang.

\section{Proses Penciptaan}

Congkak sebagai permainan rakyat yang sudah berkembang cukup lama di masyarakat Sunda khususnya di Kota Bandung, sejak dahulu memainkannya dengan menggunakan papan Congkak seperti yang tersedia saat ini. Dalam permainan tradisional, anak-anak yang hendak bermain dituntut kretivitasnya mulai dari menentukan permainan apa yang hendak dimainkan, kemudian membuat peralatan permainan, membuat dan mematuhi kesepakatan bersama hingga permainan usai.

Zaman dahulu bermain Congkak, diawali dengan membuat cekungancekungan sebagai wadah atau tempat menyimpan biji-biji yang hendak dikumpulkan. Anak-anak membuat cekungan tersebut di tanah. Dalam perkembangannya, permainan Congkak akhirnya memiliki alat permainan tersendiri, tidak lagi membuat cekungan di tanah. Alat permainan tersebut berupa papan yang terbuat dari logam, baik besi maupun kuningan, tentunya dengan beberapa cekungan sesuai dengan pola aslinya. Kemudian papan logam itu pun berganti seiring dengan bergantinya zaman, yaitu menggunakan material kayu. Perkembangan selanjutnya bergantilah material kayu dengan material plastik, yang lebih ringan, lebih praktis, dan tentunya jauh lebih murah.

Papan Congkak, yang biasanya terbuat dari kayu tetapi sekarang sudah banyak yang terbuat dari plastik, berbentuk seperti perahu dengan ukuran kurang lebih: panjang $80 \mathrm{~cm}$, lebar $15 \mathrm{~cm}$, dan tinggi $10 \mathrm{~cm}$. Pada kedua ujungnya terdapat cekungan yang lebih besar dan biasa disebut indung. Antara kedua indung tersebut berderet dua yang masing-masing terdiri atas 7 cekungan yang lebih kecil, kira-kira berdiameter $5 \mathrm{~cm}$.

Dalam bermain Congkak, selain dibutuhkan papan Congkak juga dibutuhkan kuwuk atau kerikil atau biji-bijian apa saja yang berukuran kecil. Setiap cekungan (kecuali indung) harus diisi 7 buah butir. Sehingga seluruhnya memerlukan 98 butir (dua deret X 7 lubang X 7 butir). 
Bermain Congkak dapat dilakukan kapan saja, pada waktu senggang, baik di dalam atau di luar rumah. Permainan ini pun tidak menyita banyak tempat. Permainan Congkak ini biasanya dilakukan oleh perempuan baik anak-anak maupun dewasa. Pemain berjumlah dua orang.

\section{Konteks Pertunjukan}

Pada umumnya Congkak dimainkan oleh perempuan baik anakanak maupun yang telah dewasa. Permainan yang dalam pelaksanaannya tidak menggunakan lagu ini pada umumnya dilakukan sambil duduk bersimpuh di atas lantai dan saling berhadapan dengan lawannya. Masingmasing menghadap sederet cekungan Congkak.Tidak ada ketentuan biji dari cekungan mana yang harus pertama kali diambil dalam mengawali permainan. Tetapi keduanya bersamasama meraup biji pada salah satu cekungan untuk memulai permainan, kemudian mengisi cekungan yang berderet masing-masing dengan satu butir biji yang ada dalam genggaman hasil meraup sebelumnya. Arah pengisian seperti arah jarum jam yaitu dari kanan ke kiri, sehingga cekungan indungnya terisi juga satu butir dan satu buah cekungan menjadi kosong karena bijinya diraup untuk kemudian diisikan pada cekungan lain.

Permainan dilanjutkan untuk yang kedua kali. Kedua pemain kembali meraup biji-biji yang ada dalam cekungan kecil (dalam deret miliknya), lalu diisikan pada lubang lainnya. Pengambilan biji ini perlu dilakukan seteliti mungkin, karena cekungan yang diisi tidak hanya miliknya tetapi juga milik lawannya, dan kemungkinan biji terakhir habis di cekungan lawan yang kosong. Dengan demikian seorang pemain dinyatakan kalah untuk sementara dan harus menunda permainannya hingga lawannya pun menjatuhkan biji terakhirnya dalam deret kita yang kosong dan dinyatakan kalah juga untuk sementara. Maka barulah kita melanjutkan permainan. Seperti biasa, memilih salah satu cekungan untuk diraup bijinya dan diisikan pada cekungan lain termasuk indung.

Pemain terus melanjutkan permainan dan berusaha agar dapat mengisi cekungan indung sebanyakbanyaknya dan tidak menjatuhkan biji terakhir pada cekungan kosong milik lawan. Biji milik lawan dapat menjadi milik kita dengan cara "menembak", yaitu biji terakhir kita jatuh pada cekungan kosong milik kita yang kebetulan di depannya terdapat biji lawan. Maka biji tersebut dapat diambil dan diisikan pada cekungan indung milik kita.

Bila permainan akan dilanjutkan pada babak berikutnya, cekungancekungan kembali diisi. Kemungkinan terjadi cekungan yang kosong salah seorang pemain karena biji miliknya yang tadi terkumpul dalam cekungan indung tidak cukup untuk mengisi ketujuh cekungan kecil miliknya. Hal ini disebut pecong, dan inilah yang merupakan kekalahan. Namun, bila pada deretnya masih terdapat biji-bijian maka dinyatakan sebagai meunang papan dan dialah yang akan menjadi pemain pertama pada permainan berikutnya. Permainan Congkak tidak mempunyai batas waktu, dapat dilaksanakan berulang kali dan kapan saja. 


\section{Nilai dan Potensi yang Terkandung dalam Permainan Congkak.}

Permainan ini mendidik para pemainnya, khususnya wanita agar senantiasa bersikap tenang, sebab dalam pertunjukannya memang jarang sekali didapati pemainnya banyak melakukan gerakan. Masing-masing pemain menghadap sederet cekungan Congkak. Kedekatan jarak antarpemain ini, dapat menjadi sebuah jembatan kedekatan emosional keduanya. Memberi jalan bagi para pemainnya untuk saling mengenal, mengidentifikasi, dan menumbuhkan kedekatan.

Dalam pertunjukannya, tidak ada ketentuan biji dari cekungan mana yang harus pertama kali diambil dalam mengawali permainan. Tetapi keduanya bersama-sama meraup biji pada salah satu cekungan untuk memulai permainan. Keduanya memperoleh kesempatan yang sama. Kemudian mengisi cekungan yang berderet masing-masing dengan satu butir biji yang ada dalam genggaman hasil meraup sebelumnya.

Arah pengisian seperti arah jarum jam yaitu dari kanan ke kiri, sehingga cekungan indungnya terisi juga satu butir dan satu buah cekungan menjadi kosong karena bijinya diraup untuk kemudian diisikan pada cekungan lain. Arah pengisian yang memiliki pola berputar ini sejalan dengan poros kehidupan yang terus maju dan berulang secara harmonis. Adapun jumlah biji yang digunakan berjumlah ganjil, yaitu 7 (tetapi ada juga yang menggunakan 5 buah biji).

Permainan dapat dilanjutkan untuk yang kedua kali. Kedua pemain kembali meraup biji-biji yang ada dalam cekungan kecil (dalam deret miliknya), lalu diisikan pada lubang lainnya. Pengambilan biji ini perlu dilakukan seteliti mungkin, karena cekungan yang diisi tidak hanya miliknya tetapi juga milik lawannya, dan kemungkinan biji terakhir habis di cekungan lawan yang kosong. Dengan demikian seorang pemain dinyatakan kalah untuk sementara dan harus menunda permainannya hingga lawannya pun menjatuhkan biji terakhirnya dalam deret kita yang kosong dan dinyatakan kalah juga untuk sementara. Maka barulah kita melanjutkan permainan. Seperti biasa, memilih salah satu cekungan untuk diraup bijinya dan diisikan pada cekungan lain termasuk indung. Pengulangan ini akan membawa dampak bagi keterampilan yang dimiliki, semakin sering mengulang berarti semakin sering berlatih, dan akan menuju mahir, sebagaimana kita mengenal peribahasa 'bisa karena biasa'.

Dalam permainan tradisional anak-anak Sunda, sering dikenal konsep indung dan anak, hal ini berkaitan erat dengan konsep Sunan Ambu. Dan, dalam kebudayaan Sunda sosok seorang wanita memang sangat istimewa. Adapun istilah anak yang banyak digunakan dalam permainan, bisa jadi merupakan analogi dari anak laki-laki bungsu atau tunggal, yang dalam kosmologi Sunda, anak tunggal atau bungsu itu adalah "anak ibu". Karena terhitung anak terakhir, bontot, paling belakang, maka anak bungsu masuk katagori "belakang", dalam arti bagian rumah Sunda yang khusus untuk anak perempuan. Sebagai anak mamah, maka jalinan kasih sayang mereka 
sangat kuat. Itulah sebabnya banyak kisah anak tunggal yang jatuh cinta kepada ibunya sendiri, seperti guru Gantangan kepada ibundanya Kentringmanik, Guruminda kepada Sunan Ambu dalam kisah Lutung Kasarung, dan Sangkuriang kepada Dayang Sumbi dalam legenda Tangkuban Parahu.

Pemain terus melanjutkan permainan dan berusaha agar dapat mengisi cekungan indung sebanyakbanyaknya dan tidak menjatuhkan biji terakhir pada cekungan kosong milik lawan. Biji milik lawan dapat menjadi milik kita dengan cara "menembak", yaitu biji terakhir kita jatuh pada cekungan kosong milik kita yang kebetulan di depannya terdapat biji lawan. Maka biji tersebut dapat diambil dan diisikan pada cekungan indung milik kita.

Bila permainan akan dilanjutkan pada babak berikutnya, cekungancekungan kembali diisi. Kemungkinan terjadi cekungan yang kosong salah seorang pemain karena biji miliknya yang tadi terkumpul dalam cekungan indung tidak cukup untuk mengisi ketujuh cekungan kecil miliknya. Hal ini disebut pecong, dan inilah yang merupakan kekalahan. Namun, bila pada deretnya masih terdapat biji-bijian maka dinyatakan sebagai meunang papan dan dialah yang akan menjadi pemain pertama pada permainan berikutnya. Permainan Congkak tidak mempunyai batas waktu, dapat dilaksanakan berulang kali dan kapan saja.

\section{a. Nilai yang Terkandung dalam Permainan Congkak}

Beberapa nilai yang terkandung dalam permainan Congkak ini, adalah:

1) Nilai kesenangan atau kegembiraan. Dalam permainan ini, anakanak akan merasa senang dan gembira. Terlebih bagi mereka yang memang menyukai permainan Congkak ini. Perasaan senang dan gembira timbul karena anakanak berada dalam dunianya. Dan, dunia anak adalah bermain itu sendiri.

2) Nilai kebebasan. Anak-anak merasa dirinya terbebas dari tekanan ketika mereka bermain. Maka anak-anak dapat bebas mengekspresikan dan menemukan dirinya. Namun, kebebasan yang mereka peroleh tetap dalam koridor yang mempunyai nilai. Kebebasan itu tercermin dari tidak ditentukannya cekungan mana yang hendak pertama kali diraup oleh si anak. Kebebasan untuk memilih jalannya dan menerima resiko terhadap keputusan yang telah diambilnya.

3) Nilai pertemanan. Anak-anak akan lebih memupuk rasa dan nilai pertemanan, sebagai hasil interaksi dan sosialisasi diri mereka terhadap orang lain. Kemudian kedekatan emosi dan keakraban pun akan lebih mudah terjalin. Dengan jarak yang kurang lebih hanya satu meter saja terhadap lawannya, maka si anak akan lebih mudah mendapatkan kedekatan baik fisik maupun emosional temannya yang tengah jadi lawannya tersebut. Seorang anak dapat mengidentifikasi temannya 
sendiri. Mengetahui gerak-gerik dan bahasa tubuh temannnya itu, ekspresinya, kebiasaannya, bahkan apa yang dipikirkannya. Dengan bermain Congkak, maka hal tersebut menjadi media dalam mengenali seseorang, berteman, dan memupuk persahabatan dan tali persaudaraan.

4) Nilai kepatuhan. Seorang anak belajar untuk dapat dan biasa mematuhi peraturan, sebab dalam permainan Congkak ini terdapat beberapa peraturan yang harus dipenuhi. Hal ini akan menjadi awal untuk menumbuhkan kebiasaan bersikap disiplin dan patuh, serta menyadari bahwa segala sesuatu yang menjadi keinginan dapat diperoleh dari hasil keteraturan.

5) Melatih kecakapan berhitung. Kecakapan berhitung atau yang saat ini lebih dikenal dengan logical mathematics intellegence menjadi nilai yang cukup dominan dalam permainan ini. Sebab anak dilatih untuk menggunakan kecakapan berhitungnya dalam memilih biji yang akan diraup untuk dapat memenuhi cekungan indungnya dengan banyak juga cepat.

6) Melatih kecakapan berpikir. Melatih kecakapan berpikir atau mengatur strategi merupakan bagian yang tidak akan terpisahkan dari sebuah permainan, apalagi permainan yang bersifat kompetisi. Dalam permainan Congkak ini, kemampuan mengatur strategi diwujudkan dalam menentukan dan memilih biji, serta mempertimbangkan kemungkinan tempat jatuhnya biji terakhir yang mungkin akan menghasilkan banyak biji lawan untuk mengisi cekungan indung (nembak).

7) Nilai kejujuran dan sportifitas. Nilai kejujuran sangat dilatih dalam permainan ini, sebab dalam pelaksanaannya sangat mudah sekali untuk seorang pemain berlaku curang. Misalnya dengan cara tidak memasukkan biji pada tempatnya, atau justru memasukkan beberapa biji sekaligus dalam satu cekungan. Atau bahkan meraup biji yang bukan haknya. Di sinilah seorang anak dapat dilatih jujur, dan tetap sportif. Menang atau kalah bukanlah perkara, tetapi kemenangan yang paling hebat adalah berhasil memenangkan pertarungan emosi.

8) Melatih kesabaran. Kesabaran menjadi bagian yang tak kalah pentingnya dalam pelaksanaan permainan ini. Seorang pemain harus sabar menunggu gilirannya untuk bermain, terlebih jika lawannya tangguh dan berhasil "mengocok" permainan.

9) Melatih keuletan dan ketelitian. Seorang pemain dilatih keuletannya melalui gerakan tangan yang mengisikan biji satu per satu ke dalam cekungan yang tersedia, tanpa ada yang terlewat. Hal ini melatih ketelitian seorang anak, dan memberikan pengalaman bahwa dalam mencapai satu titik (indung) perlu melewati banyak hal (cekungan-cekungan anak).

Nilai-nilai budaya dan manfaat yang terkandung dari permainan tradisional anak pada dasarnya 
diperoleh dari karakteristik permainan tradisional anak-anak itu sendiri yang lebih banyak bersifat mengelompok atau dimainkan minimal oleh dua orang anak, menggunakan alat permainan yang relatif sederhana serta mudah dicari, serta mencerminkan kepribadian bangsa sendiri. Permainan tradisional merupakan hasil penggalian dari budaya kita sendiri.

Permainan tradisional anak-anak dapat melatih anak-anak untuk bisa menguasai diri, menghargai atau mengakui kekuatan orang lain, berlatih untuk bersiasat atau bersikap yang tepat dan bijaksana. Dengan demikian, permainan anak sungguh bermanfaat untuk mendidik perasaan diri dan sosial, berdisiplin, tertib, bersikap awas dan waspada serta siap menghadapi semua keadaan. Permainan tradisional anak-anak yang dimainkan menunjukkan secara langsung bahwa permainan itu diterima dengan senang hati bagi anak itu sendiri. Mereka dapat bermain, berekspresi dan bebas merdeka. Jadi, anak-anak yang bermain dengan rasa kemerdekaan tanpa ada paksaan dan ini akan menjadikan anak-anak mempunyai rasa percaya diri.

Permainan itu bukan sekadar gerakan atau sikap yang tidak mempunyai pengaruh apabila ditanamkan kepada anak-anak. Maksudnya ada manfaat yang dapat diambil dari gerakan-gerakan di dalam permainan itu. Secara kasat mata saja, jika kita meninjaunya dari segi kesehatan, kita dapat melihat gerakan-gerakan yang terdapat dalam permainan itu dapat melatih motorik anak sehingga gerakan badannya dan sistem syarafnya akan lebih terkoordinasi dengan baik.

Ditinjau dari segi sosial, sikapsikap yang terdapat dalam permainan dapat menjadi pembentuk kepribadian seseorang, di antaranya adalah sikap positif, setiakawan, tekun, menghargai, dan masih banyak lagi, yang secara tidak langsung telah dilatihkan. Menyimak dari hasil analisis mengenai kandungan yang terdapat dalam permainan tradisional anak-anak, adalah bahwa permainan ini merupakan salah satu budaya yang berharga dalam rangka memelihara tata nilai kehidupan bangsa. Dan, melalui hasil penelitian ini telah ditemukan fungsi dan potensi yang dapat dijadikan sebuah tawaran sekaligus pilihan, sebab nyatanya permainan tradisional anak-anak ini juga dapat memberikan sumbangan yang berarti dalam membangun pribadi seseorang.

\section{b. Potensi Permainan Congkak terhadap Perkembangan Kognitif Anak}

Potensi yang terkandung dalam permainan tradisional anak-anak, di antaranya yaitu:

1) Merangsang perkembangan kognitif. Dengan bermain, sensori-motor (indera pergerakan) anak dapat mengenal ukuran besar-kecil seperti cekungan, jumlah sedikit dan banyak terkait kuwuk yang diraup dan digenggamnya, serta keterampilan menggenggam banyak sambil mengeluarkan, seperti ketika anak telah meraup kuwuk dan membaginya kembali satu per satu pada setiap cekungan sesuai putaran. Permainan fisik akan mengajarkan anak akan batas kemampuannya sendiri. Permainan juga akan meningkatkan kemampuan abstraksi (imajinasi dan fantasi) sehingga anak-anak 
semakin jelas mengenal konsep besar-kecil, atas-bawah, dan penuh-kosong. Melalui permainan anak-anak dapat menghargai aturan, keteraturan, dan logika.

2) Membangun kemampuan kognitif. Kemampuan kognitif mencakup kemampuan mengidentifikasi, mengamati dan meramalkan: mana baris dan cekungan lawan, jumlah kuwuk yang menjadi miliknya dan milik lawan, kemampuan bermain lawan, kelicikan yang mungkin digunakan lawan; mengelompokkan, anak mengelompokkan setiap cekungan berisi 7 butir kuwuk, kelompok kuwuk yang masih menjadi perebutan dan kuwuk yang telah menjadi milik masingmasing pemain, kelompok kuwuk yang ada dalam cekungan yang akan bertambah atau berkurang karena diambil, dan kuwuk dalam genggaman yang siap dibagikan; mengurutkan, anak mengurutkan pembagian kuwuk satu per satu pada setiap cekungan sesuai arah yang berlaku; membedakan dan membandingkan, yang paling penting adalah anak dapat membedakan mana wilayahnya dan mana wilayah lawan, membedakan sedikit dan banyak, dan pembedaan lain yang berlaku dalam aturan misalnya cekungan yang masih harus diisi dan yang tidak jika salah satu pemain mengalami pecong; menentukan hubungan sebab-akibat, ketika anak mengambil cekungan dengan jumlah kuwuk tertentu, misalnya ketika ia hendak menjadikan cekungan indung sebagai akhir maka ia perlu memilih cekungan yang jumlah kuwuknya sama dengan jumlah langkah sampai ke indung, memilih antara bermain berkeliling membagikan kuwuk satu persatu atau menembak terkait dengan cepat atau tidaknya cekungan indung miliknya terisi; dan menarik kesimpulan, anak dapat mengetahui pula permainan mulai dari awal bermain biasanya mengambil cekungan yang ada di posisi 7 langkah dari cekungan indung agar kuwuk terakhirnya tepat masuk ke dalam cekungan indung, dan kemudian bebas memilih cekungan mana lagi yang akan diraup, anak berusaha menyimpulkan pola-pola dan teknik bermainnya untuk mencapai kemenangan dan menghadapi lawan sesuai dengan pengalamannya. Permainan ini akan mengasah kepekaan anakanak mengenai keteraturan, urutan, dan waktu. Permainan juga meningkatkan kemampuan logis (logika).

3) Belajar memecahkan masalah. Di dalam permainan anak-anak akan menemui berbagai masalah, sehingga bermain akan memberikan kesempatan kepada anak untuk mengetahui bahwa ada beberapa kemungkinan untuk memecahkan masalah, misalnya: kelicikan lawan, jumlah kuwuk dalam cekungan indungnya masih sedikit sehingga perlu teknik untuk mengejar ketertinggalan tersebut, misal dengan cara menembak cekungan lawan. Permainan juga memungkinkan anak-anak bertahan lebih lama menghadapi kesulitan sebelum 
persoalan yang ia hadapi dapat dipecahkan. Proses pemecahan masalah ini mencakup adanya imajinasi aktif anak-anak. Imajinasi aktif akan mencegah timbulnya kebosanan yang merupakan pencetus kerewelan pada anak-anak.

4) Mengembangkan rentang konsentrasi. Apabila tidak ada konsentrasi atau rentang perhatian yang memadai, seorang anak tidak mungkin dapat bertahan lama. Ada hubungan yang dekat antara imajinasi dan kemampuan konsentrasi. Imajinasi membantu meningkatkan kemampuan konsentrasi. Anak-anak yang tidak imajinatif memiliki rentang perhatian (konsentrasi) yang pendek dan memiliki kemungkinan besar untuk berperilaku agresif dan mengacau. Hal ini nampak sekali dalam bermain congkak, anak dapat belajar mengembangkan rentang konsentrasi ketika dia harus memegang kendali permainan. Ketika anak menentukan cekungan yang diraup, serta membagikannya satu persatu tanpa terlewat, kemudian menjatuhkan kuwuk terakhir pada satu cekungan dan dengan segera mengambil seluruh kuwuk yang ada pada cekungan tersebut. Biasanya kecepatan dan ketelitian melakukan hal tersebut akan memperlihatkan konsentrasi yang dimiliki. Hal ini juga nampak ketika anak harus memperhatikan lawannya bermain. Ia perlu berkonsentrasi pada apa yang dilakukan lawan, sebab jika ia lengah maka bukan tak mungkin lawan akan berbuat curang. Juga, ia perlu tahu di mana lawannya terakhir menjatuhkan kuwuk, agar dia dapat mempertimbangkan langkah yang harus diambilnya.

5) Meningkatkan sikap sosial. Ketika bermain, anak-anak harus memerhatikan cara pandang teman bermainnya, dan dengan demikian akan mengurangi sikap egosentrisnya. Dalam permainan itu pula anak-anak dapat belajar bagaimana bersaing dengan jujur, sportif, tahu akan haknya, dan peduli akan hak orang lain.

6) Kestabilan emosi. Adanya tawa, senyum, dan ekspresi kegembiraan lain mempunyai pengaruh jauh di luar wilayah bermain itu sendiri. Adanya kegembiraan/perasaan senang yang dirasakan bersama ini dapat mengarah pada kestabilan emosi anak-anak.

7) Rasa kompetensi dan percaya diri. Bermain menyediakan kesempatan kepada anak-anak untuk mengatasi situasi. Kemampuan mengatasi situasi ini membuat anak merasa kompeten dan berhasil. Perasaan mampu ini pula yang akan mengembangkan percaya diri anak-anak. Selain itu, anak-anak dapat membandingkan kemampuan pribadinya dengan temantemannya sehingga dia dapat memandang dirinya lebih wajar (mengembangkan konsep diri yang realistis).

8) Mengatasi konflik. Di dalam bermain sangat mungkin akan timbul konflik antara satu anak dengan lainnya dan karena itu anak-anak bisa belajar memilih alternatif untuk menyikapi atau menangani konflik yang ada, misalnya salah seorang anak 
berlaku curang, atau ada pemahaman yang berbeda mengenai pola permainan.

9) Melatih kecakapan berhitung. Kedua permainan ini dapat dijadikan media pembelajaran bagi seorang anak untuk melatih keterampilan berhitungnya. Dalam permainan Congkak, seorang anak dituntut untuk mampu menghitung cepat, ketika ia harus memilih cekungan mana yang akan diraupnya. Sebab biji dalam cekungan itu akan menentukan perhentian terakhirnya, apakah akan di cekungan indung atau menembak biji lawan yang jumlahnya berlimpah. Operasi pembagian sangat kentara di sini, yaitu bagaimana dan berapa jumlah sebuah bilangan dibagi satu, maka hasilnya adalah bilangan itu sendiri, yaitu ketika seorang pemain harus membagikan bijihnya satu per satu setelah ia meraup sebuah cekungan. Kemudian operasi penambahan suatu bilangan dengan satu, ketika seorang anak menjatuhkan biji terakhirnya dan akan meraup biji selanjutnya. Dalam permainan ini, sekalipun seorang anak akan melakukan kelicikan atau tindakan yang tidak sportif, maka tindakan tersebut pun membutuhkan dan akan melatih keterampilan dalam berhitung.

Operasi pengalian yang dapat ditarik dari permainan ini adalah jumlah biji yang digunakan dalam permainan, yaitu sebanyak $7 \times 7 \times 2$, yaitu tujuh buah biji dikalikan dengan 7 buah cekungan yang tersedia, dikalikan lagi dengan dua, karena jumlah deret cekungannya ada dua. Maka diperolehlah hasil 98, yang merupakan total keseluruhan biji yang dipergunakan dalam permainan ini. Operasi pembagian bilangan dengan variabel 7 , dapat dilakukan pada babak kedua, yaitu ketika masing-masing pemain mengisi cekungannya dengan biji yang telah ia kumpulkan dalam cekungan indung sebagai hasil dari permainan pada babak pertama. Operasi penjumlahan dan pengurangan, dapat dilakukan ketika menghitung sisa biji yang tersedia pada masing-masing pemain, setelah dituangkan ke dalam deret cekungan miliknya.

\section{PENUTUP}

Nilai budaya dan potensi serta manfaat yang terkandung dari permainan tradisional anak pada dasarnya diperoleh dari karakteristik permainan tradisional anak-anak itu sendiri yang lebih banyak bersifat mengelompok atau dimainkan minimal oleh dua orang anak, menggunakan alat permainan yang relatif sederhana, serta mencerminkan kepribadian bangsa sendiri. Menyimak dari hasil analisis mengenai nilai dan potensi yang terdapat dalam permainan congkak, permainan ini merupakan salah satu warisan budaya yang berharga dalam rangka memelihara tata nilai kehidupan bangsa. Hasil penelitian ini dapat dijadikan sebuah tawaran sekaligus pilihan, sebab nyatanya permainan tradisional anak-anak ini juga dapat memberikan sumbangan yang berarti dalam membangun pribadi seseorang.

Permainan tradisional yang sarat dengan nilai dan potensi itu perlu dikenali, selanjutnya dapat diimprovisasi sehingga akan diminati oleh anakanak. Guna mengembangkan permain- 
an tradisional anak-anak sebagai salah satu aset budaya bangsa, maka perlu kiranya mendapat perhatian dari berbagai pihak. Mulai dari masyarakat itu sendiri hingga campur tangan pemerintah. Semua ini tidak lepas dari usaha untuk membentuk kepribadian anak-anak yang nantinya akan menjadi penerus perjuangan bangsa, menjadi manusia yang berbudi luhur dan dapat membawa bangsa ini pada suatu kondisi yang lebih baik.

\section{DAFTAR PUSTAKA}

Danandjaja, James. 2002.

Folklor Indonesia. Jakarta: Grafiti

Miller, Patricia H. 1993.

Theories of Development Psychology. New York: Freeman

Tim Peneliti. 1981.

Permainan Daerah Jawa Barat. Jakarta: Depdikbud 